\title{
PERAN GURU DALAM MENGGUNAKAN MODEL CONTEXTUAL TEACHING AND LEARNING (CTL) DI SEKOLAH DASAR
}

\author{
Dahlia Mei Frida Silitonga ${ }^{1}$, Elpri Darta Putra ${ }^{1}$ \\ ${ }^{1}$ Universitas Islam Riau, Pekanbaru \\ *Corresponding Address: dahliameifrida@gmail.com
}

Naskah diterima: 15 September 2021| Disetujui: 1 Oktober 2021 | Diterbitkan: 3 Oktober 2021

\begin{abstract}
To organize subject matter with students' daily lives, teachers need to choose the right learning model for teaching. This study aims to describe the teacher's role in using the contextual teaching and learning (CTL) learning model in thematic learning for fifth grade students of Pekanbaru Adventist elementary school. This type of research is descriptive qualitative research. The subjects of this study were 3 fifth grade teachers and 5 fifth grade students. The data analysis technique used the Milles and Huberman model with stages, data reduction, data presentation, and drawing conclusions. The results of the study indicate the teacher's role in using the CTL model in the thematic learning process. This can be seen from the teacher doing planning such as preparing the lesson plan, then the teacher carries out the learning process using the CTL model. Furthermore, the teacher also evaluates the learning outcomes that have been carried out. The conclusion of this study is that the teacher has carried out the learning process in accordance with the steps of the CTL model in thematic learning.
\end{abstract}

Keywords: Teachers; Learning Models; Contextual teaching and learning

\begin{abstract}
Abstrak: Kurangnya guru dalam mengorganisasikan materi dengan kehidupan aktual siswa mengakibatkan proses pembelajaran tampak tidak bermakna. Untuk mengorganisasikan materi pelajaran dengan kehidupan sehari-hari siswa, guru perlu memilih model pembelajaran yang tepat untuk mengajar. Penelitian ini bertujuan untuk mendeskripsikan peran guru dalam menggunakan model pembelajaran contextual teaching and learning (CTL) pada pembelajaran tematik untuk siswa kelas V sekolah dasar Advent Pekanbaru. Jenis penelitian ini adalah penelitian kualitatif deskriptif. Subjek penelitian ini adalah 3 orang guru kelas V, serta 5 orang siswa kelas V. Teknik analisis data menggunakan model Milles and Huberman dengan tahapan, reduksi data, penyajian data, dan penarikan kesimpulan. Hasil penelitian menunjukkan peran guru dalam menggunakan model CTL dalam proses pembelajaran tematik. Hal ini terlihat dari guru melakukan perencanaan seperti mempersiapkan RPP, selanjutnya guru melaksanakan proses pembelajaran menggunakan model CTL. Selanjutnya guru juga mengevaluasi hasil pembelajaran yang telah dilakukan. Kesimpulan dari penelitian ini adalah guru sudah melakukan proses pembelajaran sesuai dengan langkah-langkah model CTL dalam pembelajaran tematik.
\end{abstract}

Kata kunci: Guru; Model Pembelajaran; Contextual teaching and learning 


\section{PENDAHULUAN}

Pendidikan merupakan usaha sadar dan terencana untuk mewujudkan proses pembelajaran dan suasana belajar agar peserta didik aktif dalam mengembangkan potensial dirinya yang memiliki kecerdasan, keterampilan, kepribadian yang diperlukan peserta didik ketika bermasyarakat, berbangsa, dan bernegara. Pendidikan merupakan tuntutan dalam hidup tumbuhnya anak, pendidikan dapat menjadikan anak sebagai orang yang berguna bagi nusa dan bangsa serta pendidikan dapat membawa anak ke kehidupan yang lebih baik. Kemampuan yang terjadi pada diri untuk suatu proses yang kompleks sepanjang masa hidup dapat dilakukan dengan proses belajar.

Belajar adalah suatu perubahan prilaku yang relatif permanen dan dihasilkan dari pengalaman masa lalu atau pun pembelajaran yang bertujuan atau direncanakan (Setiawati, 2018). Pada proses pembelajaran yang sedang berlangsung seorang siswa mengalami kurangnya ketertarikan untuk bisa selalu fokus dalam proses belajar ataupun pembelajaran pada tingkat pendidikan. Hal ini menjadi suatu dampak pada suatu hasil pembelajaran yang jauh dari ekspetasi hasil yang diharapkan. Tentunya perlu ada proses upaya dalam memperbaiki suatu proses pembelajaran yaitu salah satunya menggunakan suatu model pembelajaran.

Salah satu usaha yang dapat guru lakukan yaitu dalam melakukan kegiatan belajar mengajar dengan menggunakan model pembelajaran. Model pembelajaran merupakan suatu cara atau strategi yang dilakukan oleh seorang guru dalam melaksanakan kegiatan belajar-mengajar, di mana dalam kegiatan tersebut melibatkan siswa sebagai penerima pengetahuan dari kegiatan pembelajaran (Istiningsih et al., 2018). Ketercapaian suatu tujuan pembelajaran guru memerlukan model pembelajaran. Model pembelajaran yang digunakan guru harus dapat menumbuhkan kemampuan siswa untuk berbagai tujuan pembelajaran. Oleh karena itu, guru harus mengetahui dan memahami tentang model pembelajaran agar proses belajar di kelas lebih menyenangkan dan menumbuhkan kemampuan siswa.

Terdapat beberapa faktor yang mempengaruhi adanya pendidikan yang berkualitas, salah satu faktornya adalah guru (Udiat, 2019). Signifikansi peran guru adalah menjadi garda terdepan di sekolah bagi anak, gurulah yang berhadapan langsung dengan masalah kegiatan belajar mengajar di kelas (Buchari, 2018). Sebagai perancang dan pelaksanan kegiatan pembelajaran, guru dapat merancang dan mempersiapkan semua komponen agar berjalan dengan efektif dan efesien. Untuk itu, guru harus memiliki pengetahuan yang cukup memadai tentang prinsip-prinsip belajar, sebagai landasan dari perencanaan. Proses belajar mengajar merupakan inti dari proses pendidikan secara keseluruhan dengan guru sebagai pemegang peranan utama. Maka, dibutuhkan berbagai peran seorang guru dalam menciptakan situasi dan kondisi belajar yang menyenangkan di kelas. 
Guru yang kreatif akan selalu berusaha menggunakan model pembelajaran yang terbaik bagi siswanya. Seorang guru juga hendaknya terampil dalam menggunakan model yang dipilih. Apabila keterampilan guru mencukupi maka kemanfaatan model akan dirasakan sendiri oleh guru maupun siswa, untuk itu diperlukan keterampilan dan peran guru dalam menggunakan model pembelajaran selama proses pembelajaran berlangsung. Diharapkan guru dapat menghubungkan antara konten materi ajar dengan situasi-situasi dunia nyata dan memotivasi peserta didik untuk menguasai hubungan tersebut. CTL merupakan suatu konsepsi yang membantu pendidikan untuk mengintegrasikan materi yang akan diajarkan dengan kehidupan aktual siswa (Jamalia, 2018). Pembelajaran kontekstual merupakan strategi pembelajaran yang menekankan materi yang akan dipelajari kemudian dihubungkan dengan kehidupan sosial siswa (Hafifah et al., 2019).

Berdasarkan hasil studi pendahuluan peneliti yang dilakukan dengan guru wali kelas $\mathrm{V}$ di Sekolah Dasar Advent Pekanbaru tentang peran guru dalam menggunakan model Contextual Teaching and Learning (CTL), hasil observasi menunjukan bahwa peran guru dalam menerapkan model pembelajaran CTL untuk siswa kelas V masih belum optimal. Hal ini dapat dilihat ketika 1) siswa tidak termotivasi dalam belajar, 2) metode ceramah masih dominan dilakukan di kelas, 3) siswa kurang memerhatikan guru saat proses belajar mengajar berlangsung, 4) ketika ditanya terkait materi, siswa kebingungan dalam menjawabnya, 5) guru tidak mengaitkan materi dengan situasi nyata/kehidupan sehari-hari siswa.

Maka dari itu, peneliti tertarik ingin melakukan penelitian di Sekolah Dasar Advent Pekanbaru. Peneliti ingin mengetahui serta mendeskripsikan bagaimana peran guru dalam menggunakan model pembelajaran contextual teaching and learning (CTL) di kelas V sekolah dasar.

\section{METODE}

Sesuai dengan masalah yang akan dibahas oleh peneliti, penelitian ini menggunakan pendekatan kualitatif. Menurut Alwasilah (dalam Dafit \& Ramadan, 2020) sesuai dengan salah satu karakteristik penelitian deskriptif kualitatif yaitu untuk mengeksplor sebuah permasalahan atau fenomena sosial dan mengembangkan pemahaman yang spesifik dari suatu fenomena. Penelitian kualitatif dilakukan secara intensif, peneliti ikut berpatisipasi lama di lapangan, mencatat secara hatihati apa yang terjadi, melakukan analisis reflektif terhadap berbagai dokumen yang ditemukan di lapangan, dan membuat laporan penelitian secara mendetail (Sugiyono, 2017). Pada penelitian ini penulis memposisikan diri sebagai instrument tunggal, di mana selama proses pengumpulan data, peneliti terjun sendiri ke lapangan untuk memperoleh data. 
Subjek pada penelitian ini adalah 3 orang guru kelas V serta 5 orang siswa kelas V di SD Advent Pekanbaru. Teknik pengambilan subjek yaitu teknik purposive sampling. Teknik purposive sampling merupakan teknik pengambilan sampel data dengan pertimbangan tertentu. Pertimbangan tertentu ini, misalnya orang tersebut yang dianggap paling tahu tentang apa yang dibutuhkan oleh peneliti, atau mungkin dia sebagai penguasa sehingga akan memudahkan peneliti menjelajah obyek/situasi sosial yang diteliti (Sugiyono, 2017)..

Pada penelitian ini, data diperoleh berdasarkan hasil observasi, wawancara, dan analisis dokumen. Peneliti melakukan wawancara dengan guru kelas V serta siswa kelas V SD Advent Pekanbaru terkait peran guru dalam menggunakan model pembelajaran CTL pada pembelajaran tematik. Setelah peneliti melakukan kegiatan wawancara, peneliti melakukan kegiatan observasi. Kegiatan observasi dilakukan 3 kali selama proses pembelajaran. Peneliti mengikuti kegiatan belajar mengajar di dalam kelas V dari awal sampai akhir pembelajaran. Peneliti juga melakukan analisis dokumen seperti RPP, Silabus, Buku Guru dan Buku Siswa serta buku lembar kerja siswa (LKS).

Keabsahan data terdiri dari beberapa kriteria yang sudah ditentukan antara lain kepercayaan, keteralihan, kebergantungan dan kepastian (Hadi, 2016). Hasil penelitian ini dapat dipertanggungjawabkan dengan adanya keabsahan hasil penelitian yang disebut dengan keabsahan data. Uji keabsahan data penelitian ini menggunakan uji kreadibilitas yaitu uji kreadibilitas atau kepercayaan terhadap hasil penelitian menggunakan teknik trianggulasi.

Triangulasi merupakan teknik pemeriksaan keabsahan data yang menggunakan sumber diluar data tersebut atau membandingkan triangulasi dengan sumber data (Alfansyur \& Mariyani, 2020). Dalam penelitian ini digunakan teknik triangulasi sumber yang dicapai melalui cara membandingkan data hasil pengamatan dengan data hasil wawancara. Sedangkan triangulasi teknik yaitu mengecek data kepada sumber yang sama dengan teknik berbeda.

Data yang telah dikumpulkan melalui teknik wawancara, observasi serta analisis dokumen selanjutnya di analisis. Pada penelitian ini, untuk menganalisis data peneliti menggunakan model Milles and Huberman dengan 3 tahapan yaitu reduksi data, penyajian data, dan penarikan kesimpulan.

\section{HASIL \& PEMBAHASAN}

Penelitian ini dilaksanakan di kelas V SD Advent Pekanbaru. Di SD Advent Pekanbaru, sudah menerapkan kurikulum 2013 dan juga sudah menerapkan pembelajaran tematik di dalam proses pembelajaran yang sesuai dengan penekanan kurikulum 2013. Pembelajaran tematik adalah salah satu model dalam pembelajaran terpadu yang menekankan keterlibatan siswa dalam pembelajaran (Muklis, 2012). Tematik diberikan dengan maksud menggabungkan konten kurikulum dalam unit- 
unit atau satuan-satuan yang utuh serta membuat proses pembelajaran lebih terpadu, bermakna, dan mudah dipahami oleh siswa tingkat sekolah dasar (Sungkono, 2006). Penelitian ini dilakukan untuk mendeskripsikan bagaimana peran guru dalam menggunakan model pembelajaran Contextual Teaching and Learning (CTL) yang terlihat pada pembelajaran tematik di SD Advent Pekanbaru. Berikut merupakan deskripsi hasil penelitian yang dilakukan di kelas V SD Advent Pekanbaru.

\section{Deskripsi Data Penelitian mengenai Pembelajaran Tematik Di SD Advent Pekanbaru}

Dalam pelaksanaan kegiatan pembelajaran tematik guru menggunakan berbagai macam metode dan strategi agar KI dan KD yang telah ditetapkan dapat tercapai dengan hasil yang maksimal. Pelaksanaan pembelajaran tematik dilaksanakan sesuai dengan silabus dan rencana pelaksanaan pembelajaran (RPP) yang telah dibuat sehingga kegiatan pembelajaran tematik dapat berjalan secara efisien.

Di antara tema pembelajaran tematik peneliti melakukan penelitian pada saat tema 8 (lingkungan sahabat kita), subtema 1 (manusia dan lingkungan). Seorang guru memulai pembelajaran dengan mengucapkan salam dan tidak lupa untuk berdoa dan selanjutnya menyanyikan lagu Nasional bersama-sama. Kemudian guru menyampaikan tujuan pembelajaran. Kegiatan inti diisi guru dengan memberikan penjelasan materi yang akan dipelajari kemudian memperlihat video pembelajaran yang diambil dari youtube yang memuat tentang materi yang akan diajarkan, setelah itu guru memberikan penguatan yang di hubungkan ke situasi nyata siswa (kehidupan sehari-hari siswa). Guru dan siswa saling bertanya jawab. Selanjutnya kegiatan penutup diakhiri dengan pemberian tugas/evaluasi kepada seluruh siswa, setelah itu guru menutup pembelajaran dengan salam.

\section{Deskripsi Data Penelitian mengenai Peran Guru dalam Menggunakan Model Pembelajaran Contextual Teaching and Learning (CTL) Di SD Advent Pekanbaru}

Dalam menerapkan model Contextual Teaching and Learning (CTL) ini membutuhkan peran guru untuk meningkatnya hasil dari kegiatan permbelajaran. Seorang guru memiliki banyak peran diantaranya guru sebagai pendidik, guru sebagai pengajar dan guru sebagai pembimbing.

a. Guru sebagai perencana (planner)

Sebelum guru melaksanakan pemanfaatan model dalam pembelajaran tersebut, guru perlu membuat perencanaan. Tanpa perencanaan yang baik, pelaksanaan pembelajaran tidak akan berjalan dengan lancar. Dalam penggunaan model pembelajaran CTL tentu ada pedoman yang menjadi acuan bagi guru dalam perencanaan penggunaan model pembelajaran.

Peneliti melakukan wawancara untuk mengetahui perencanaan apa yang harus dipersiapkan oleh guru sebelum melaksanakan proses pembelajaran. Hasil wawancara dengan tiga narasumber, 
yaitu Ibu (SM) pada hari Senin 09 Agustus 2021, Ibu (BS) pada hari Kamis 12 Agustus 2021, Ibu (ES) pada hari Senin 16 Agustus 2021 yang menyatakan bahwa Rencana Pelaksanaan Pembelajaran menjadi pedoman guru dalam melakukan kegiatan pembelajaran untuk mencapai tujuan pembelajaran yang telah dirancang dan diharapkan oleh guru. Menurut ketiga narasumber, dalam mengidentifikasi materi pembelajaran, hal yang perlu dipertimbangkan yaitu disesuaikan dengan silabus, keadaan siswa, menambahkan materi yang dekat dengan siswa dan alokasi waktu. Dalam menentukan tujuan pembelajaran menggunakan aspek atau rumus ABCD. Audiens (Siswa), Behavior (perilaku), Condition (kondisi yang perlu dipenuhi agar perilaku yang diharapkan dapat tercapai, dan Degree (tingkat penampilan yang dapat diterima). Untuk membantu kegiatan pembelajaran guru dapat menentukan model pembelajaran yang disesuaikan dengan karakteristik siswa.

Dalam menyusun Rencana Pelaksanaan Pembelajaran (RPP) langkah-langkah yang sulit untuk diterapkan yaitu pertama, merumuskan indikator karena harus disesuaikan dengan KKO karena dikhawatirkan tingkatan yang digunakan terlalu tinggi untuk siswa. Kedua, dalam penjabaran kegiatan inti karena membutuhkan sedikit waktu dalam penyusunannya. Ketiga, penilaian itu harus sesuai dengan kompetensi dasar, indikator, tujuan pembelajaran.

Peraturan pemerintah yang merubah rencana pelaksanaan pembelajaran (RPP) dari 10 lembar menjadi 1 lembar juga akan menjadi kendala guru karena belum memahami bagaimana susunan rencana pelaksanaan pembelajaran yang terbaru. Berdasarkan hasil wawancara yang telah dilakukan, dapat disimpulkan bahwa guru telah membuat RPP dengan tujuan agar kegiatan pembelajaran tersebut tersusun dan terencana.

Demi mendapatkan kebenaran data hasil wawancara tersebut peneliti melaksanakan kegiatan observasi dengan mengikuti pembelajaran tematik yang diajarkan oleh guru 1 pada hari Rabu tanggal 18 Agustus 2021, guru 2 pada hari Kamis tanggal 19 Agustus 2021, dan guru 3 pada hari Jumat tanggal 20 Agustus 2021, teramati guru melaksanakan pembelajaran sesuai dengan langkah-langkah yang tercantum di Rencana Pelaksanaan Pembelajaran (RPP). Kemudian dari hasil observasi yang dilakukan, menunjukkan bahwa bentuk perencanaan yang dilakukan sebelum dilaksanakannya proses pembelajaran dalam menerapkan model Contextual Teaching and Learning (CTL) pada materi tematik untuk siswa kelas $\mathrm{V}$ adalah pembuatan RPP.

\section{b. Guru sebagai Pelaksana}

Selain berperan dalam kegiatan perencanaan, seorang guru juga berperan dalam pelaksanaan proses pembelajaran. Pelaksanaan dengan menggunakan model pembelajaran Contextual Teaching and Learning (CTL) dalam pembelajaran dapat dijelaskan sebagai berikut: 
1) Proses pembelajaran tatap muka

Berdasarkan hasil wawancara dengan guru 1 Ibu (SM) pada hari Senin 09 Agustus 2021, guru 2 Ibu (BS) pada hari Kamis 12 Agustus 2021, dan guru 3 Ibu (ES) pada hari Senin 16 Agustus 2021, yang menyatakan bahwa dalam proses pembelajaran tatap muka dikelas, model pembelajaran yang digunakan adalah model pembelajaran Contextual Teaching and Learning (CTL). Peneliti juga melakukan wawancara dengan lima orang siswa berinisial NAS, MA, BAP, MRH dan RD pada hari Rabu-Kamis tanggal 18-19 Agustus 2021, yang menyatakan bahwa guru dalam menjelaskan materi pelajaran selalu menanyakan pengalaman siswa.

Demi mendapatkan kebenaran data hasil wawancara tersebut peneliti melaksanakan kegiatan observasi dengan mengikuti pembelajaran tematik yang di ajarkan oleh guru 1 pada hari Rabu tanggal 18 Agustus 2021, guru 2 pada hari Kamis tanggal 19 Agustus 2021, dan guru 3 pada hari Jumat tanggal 20 Agustus 2021, teramati guru memanfaatkan model pembelajaran Contextual Teaching and Learning (CTL) dalam pembelajaran tatap muka. Adapun observasi yang telah peneliti amati, sebagai berikut:

a) Guru 1 (kelas VA): Guru 1 memberikan penjelasan materi kepada siswa dengan menggunakan model CTL tentang siklus air pada tema 8 (lingkungan sahabat kita), subtema 1 (manusia dan lingkungan), pembelajaran ke-2. Guru memberikan appersepsi seperti “Apakah anak-anak sering mandi hujan?”, "Bagaimana hujan itu bisa turun dari langit?”.

b) Guru 2 (kelas VB): Guru 2 memberikan penjelasan materi kepada siswa dengan memanfaatkan media powerpoint. Di dalam powerpoint tersebut juga terdapat video pendek terkait materi pelajaran. Pembelajaran tentang tema 8 (lingkungan sahabat kita), subtema 1 (manusia dan lingkungan), pembelajaran ke-4 tentang jenis-jenis usaha masyarakat Indonesia. Guru selalu mengaitkan materi ajar dengan kehidupan siswa seperti "Apakah anak Ibu pernah membeli mainan atau membeli jajanan?”, “Apakah anak-anak pernah mendengar pekerjaan berdagang?" Apakah ada yang orang tuanya berdagang?"

c) Guru 3 (kelas VC): Pada saat peneliti melakukan observasi, guru 3 dalam memberikan penjelasan materi terkait tema 8 (lingkungan sahabat kita), subtema 1 (manusia dan lingkungan), pembelajaran ke-3 tentang jenis usaha dengan mengolah sumber daya alam seperti jenis usaha bidang produksi yang bergerak dalam pengolahan sumber daya alam (hewan dan tumbuhan) disebut usaha agraris. Jenis usaha yang termasuk bidang agraris antara lain persawahan, perkebunan, perhutanan, peternakan dan perikanan. Berdasarkan hasil observasi yang telah peneliti lakukan, teramati guru selalu mengaitkan materi ajar dengan situasi nyata atau kehidupan sehari-hari siswa. 
Setelah peneliti melakukan observasi di kelas V serta analisis silabus, RPP, buku guru \& buku siswa menunjukan bahwa ada kesesuaian antara materi pelajaran dengan langkah-langkah/penerapan pembelajaran yang dilakukan.

\section{c. Guru sebagai Penilai (Evaluator)}

Setelah melalui proses perencanaan dan pelaksanaan, tugas guru selanjutnya yaitu mengevaluasi hasil pembelajaran yang telah dilakukan. Berdasarkan hasil observasi dan wawancara, data yang peneliti dapatkan mengenai proses evaluasi dari pembelajaran menerapkan model CTL bahwa kegiatan akhir yaitu kesimpulan, evaluasi dan refleksi.

Guru bersama siswa menyimpulkan hasil pembelajaran dan dilanjutkan dengan kegiatan evaluasi/penilaian. Penilaian ialah hasil yang dicapai siswa dalam proses pembelajaran. Di dalam penilaian terdiri dari tiga aspek yaitu penilaian sikap, pengetahuan dan keterampilan. Penilaian meliputi penilaian bidang kognitif, afektif dan psikomotorik.

Berdasarkan hasil wawancara, observasi dan hasil telaah dokumen mengenai penilaian yang disusun oleh guru. Guru sudah menggunakan penilaian tes dan non tes. Penilaian afektif yang digunakan oleh guru ialah penilaian diri dan penilaian antar peserta didik. Penilaian kognitif yang digunakan oleh guru ialah tes uraian dalam bentuk terbatas serta penilaian berupa pilihan ganda, essay, menjodohkan, melengkapi dan benar-salah. Penilaian psikomotorik yang digunakan oleh guru ialah skala rentang.

Setelah kegiatan menyimpulkan dan evaluasi, guru menutup pembelajaran dengan membaca hamdalah bersama-sama dilanjutkan guru mengakhiri pembelajaran dengan membaca salam yang kemudian dijawab oleh siswa.

\section{Peran Guru dalam Menggunakan Model Pembelajaran Contextual Teaching and Learning (CTL) Di SD Advent Pekanbaru}

Berdasarkan hasil penelitian di SD Advent Pekanbaru dapat diketahui bahwa peran seorang guru sangatlah penting dalam kegiatan belajar mengajar di kelas. Sosok seorang guru sangat penting dalam menentukan keberhasilan dalam kegiatan belajar mengajar serta dapat mencapai tujuan dalam pembelajaran. Sebelum kegiatan belajar mengajar dimulai, guru harus menyusun RPP, silabus, media pembelajaran serta menentukan model pembelajaran yang cocok untuk digunakan pada mata pelajaran yang akan diberikan guru.

Peran guru dalam menggunakan model Contextual Teaching and Learning (CTL) dalam proses belajar siswa di SD Advent Pekanbaru. Dengan memilih metode yang tepat, seorang guru selain dapat 
menentukan hasil lulusan dari lembaga pendidikan, juga merupakan landasan keberhasilan lembaga pendidikan, dan juga menjadi pengalaman yang disenangi bagi anak didik.

Model pembelajaran adalah cara yang dilakukan oleh guru agar proses belajar mengajar tercapai sesuai yang diharapkan. Memang perlu dengan menggunakan berbagai metode dalam pembelajaran agar proses belajar tersebut menyenangkan dan juga para siswa dapat memahami pelajaran yang dijelaskan. Dalam menerapkan model Contextual Teaching and Learning (CTL) ini membutuhkan peran guru untuk meningkatnya hasil dari kegiatan permbelajaran. Seorang guru memiliki banyak peran diantaranya guru sebagai pendidik, guru sebagai pengajar dan guru sebagai pembimbing.

\section{a. Guru sebagai Perencana (Planner)}

Peran guru sebagai pendidik merupakan tenaga profesional yang bertugas merencanakan dan melaksanakan proses pembelajaran serta menilai hasil pembelajaran di SD Advent Pekanbaru sebelum melaksanakan proses pembelajaran yaitu menerapkan model Contextual Teaching and Learning (CTL), guru telah memiliki perencanaan yang disiapkan oleh guru kelas. Berdasarkan hasil wawancara peneliti dengan guru kelas yang menyatakan bahwa sebelum mengajar tentunya seorang guru harus mempersiapkan segala sesuatu yang berkaitan dengan proses pembelajaran yang akan dilaksanakan, begitu juga dalam pembelajaran tematik yang menggunakan model Contextual Teaching and Learning (CTL). Guru telah membuat rencana pembelajaran untuk menyusun dan merencanakan kegiatan pembelajaran (Febrina et al., 2016).

Hasil wawancara di atas didukung oleh hasil observasi yang dilakukan peneliti, menunjukkan bahwa bentuk perencanaan yang dilakukan sebelum dilaksanakannya proses pembelajaran dalam menerapkan model Contextual Teaching and Learning (CTL) pada materi tematik untuk siswa kelas V adalah pembuatan RPP. Pembuatan RPP ini bertujuan agar dalam pelaksanaan proses belajar mengajarnya tertata untuk mencapai tujuan dari materi yang diajarkan, baik segi alokasi waktunya, model yang digunakan, proses pembelajarannya dan lain sebagainnya.

\section{b. Guru sebagai Pelaksana}

Selain berperan dalam kegiatan perencanaan, seorang guru juga berperan dalam pelaksanaan proses pembelajaran. Berdasarkan hasil wawancara yang peneliti lakukan bahwa didalam pelaksanaan model Contextual Teaching And Learning (CTL) ada tahap persiapan dan tahap pelaksanaan. Berdasarkan hasil wawancara guru kelas V menyatakan bahwa dalam pelaksanaan model pembelajaran CTL terdapat langkah-langkah yang dapat mempengaruhi keberhasilan dalam pembelajaran. 1) langkah penggunaan model CTL yang dapat meningkatkan pembelajaran yaitu: (a) 
pendidik memberikan materi untuk dipelajari sendiri oleh peserta didik bersama kelompok, sebelumnya pendidik juga sudah memberikan apersepsi kepada siswa mengenai materi yang akan diajarkan serta mengaitkan materi dengan kehidupan nyata/pengalaman siswa, (b) peserta didik saling bertanya jawab dibawah bimbingan pendidik, (c) peserta didik mencari pengetahuan baru dengan memecahkan masalah yang diberikan, (d) peserta didik bekerjasama dalam kelompok, (e) setiap kelompok mempresentasikan hasil kerja kelompok di depan kelas, (f) peserta didik dengan pendidik mengingat kegiatan yang telah dilakukan dan membuat kesimpulan materi yang dipelajari, $(\mathrm{g})$ peserta didik melaksanakan evaluasi secara mandiri. Hal yang senada juga diungkapkan oleh salah satu siswa SD Advent Pekanbaru yang menyatakan bahwa dalam proses pelaksanaan pembelajaran, guru memberikan pemanasan kepada siswa dengan tanya jawab terkait materi yang akan diajarkan dan mengaitkan dengan pengalaman siswa.

Berdasarkan wawancara di atas peneliti dapat menyimpulkan bahwa proses pembelajaran yang dilakukan guru dalam menggunakan model CTL terdapat beberapa poin. Pertama, guru mengkondisikan siswa untuk siap belajar dan memberikan apersepsi kepada siswa serta menyampaikan tujuan pembelajaran. Setelah melakukan apersepsi, guru menyampaikan tujuan pembelajaran yang hendak dicapai siswa. Setelah menyampaikan tujuan guru memberikan motivasi kepada siswa, agar siswa lebih bersemangat dalam belajar. Pembelajaran dilanjutkan dengan mengkonstruksikan materi pelajaran dengan kehidupan siswa dan pengalaman siswa berdasarkan apersepsi. Kemudian guru melakukan langkah kedua pada model pembelajaran CTL, yaitu pemodelan yang dilakukan guru dengan cara memberikan contoh-contoh nyata terkait materi. Langkah ketiga, yaitu guru memberikan materi agar siswa bekerja kelompok untuk menyelesaikan diskusi. Setelah itu, siswa dibagi, guru membimbing siswa dalam kegiatan diskusi. Setelah laporan selesai dibuat, masing-masing perwakilan kelompok maju ke depan untuk mempresentasikan hasil diskusi kelompok yang telah mereka buat. Langkah selanjutnya yaitu bertanya, pada kegiatan ini guru memberikan kesempatan kepada masing-masing siswa untuk bertanya mengenai materi. Lalu langkah selanjutnya adalah kegiatan penilaian

\section{c. Guru sebagai Penilai (Evaluator)}

Setelah melalui proses perencanaan dan pelaksanaan, tugas guru selanjutnya yaitu mengevaluasi hasil pembelajaran yang telah dilakukan. Berdasarkan hasil observasi dan wawancara, data yang peneliti dapatkan mengenai proses evaluasi dari pembelajaran menerapkan model CTL bahwa kegiatan akhir yaitu kesimpulan, evaluasi dan refleksi. Kegiatan ini dilakukan dengan cara mengajak siswa untuk menyimpulkan secara bersama-sama mengenai materi yang telah dibahas pada 
saat pembelajaran. Siswa diberi kesempatan untuk menyampaikan pendapatnya masing-masing di dalam menyimpulkan pembelajaran yang telah mereka lakukan.

Meskipun siswa menyimpulkan dengan pendapat masing-masing, guru tetap membimbingnya. Setelah sebagian siswa menyimpulkan hasil pembelajaran, guru memberi penguatan terhadap pemahaman siswa mengenai materi yang diberikan pada saat pembelajaran. Guru melakukan pemberian motivasi kepada siswa agar siswa termotivasi untuk berinteraksi dengan lingkungan secara aktif, mencari, dan menemukan sendiri berbagai hal yang dapat diperoleh dari lingkungan. Kegiatan guru yang memberikan kesempatan kepada siswa untuk terlihat aktif dalam pembelajaran dikemukakan Bruner (dalam Sulistyorini, 2007), penemuan itu penting bagi proses belajar siswa, yaitu dapat mengembangkan kemampuan intelektual siswa, mendapat motivasi intrinsik, menghayati bagaimana ilmu itu sendiri, dan memperoleh daya ingat yang lebih lama retensinya. Setelah itu, kegiatan selanjutnya adalah pemberian evaluasi/tugas serta tindak lanjut kepada peserta didik. Dalam proses pembelajaran CTL terlihat keinginan peserta didik yang antusias untuk berhasil mengerjakan soal-soal yang diberikan oleh pendidik. Rasa ingin tahu peserta didik yang tinggi ketika pendidik menjelaskan materi menunjukkan adanya dorongan kebutuhan belajar dan cita-cita di masa depan. Selain itu, peserta didik juga lebih bersemangat pada kegiatan pembelajaran yang menarik dan lingkungan belajar yang kondusif seperti melalui kegiatan percobaan dan diskusi. Guru sebagai evaluator yang baik adalah guru yang melakukan penilaian untuk mengetahui apakah tujuan pembelajaran sudah tercapai atau belum, apakah materi ajar sudah dikuasai siswa atau belum dan apakah model yang digunakan sudah tepat atau belum (Kirom, 2017).

\section{KESIMPULAN}

Model pembelajaran kontekstual (CTL) adalah konsep pembelajaran yang membantu guru menghubungkan materi ajar dengan situasi kehidupan nyata siswa dan mendorong mereka untuk membuat hubungan antara pengetahuan mereka dalam kehidupan sehari-harinya. Melalui penggunaan model pembelajaran kontekstual (CTL) dalam pembelajaran tematik yang dilakukan oleh guru, diharapkan siswa dapat menemukan dan mengembangkan konsep belajarnya sendiri, karena belajar bukan hanya tentang menghafal dan mengingat fakta, melainkan belajar sebagai suatu usaha dalam mengoptimalkan potensi siswa dari segi kognitif, afektif dan psikomotorik. Dalam menerapkan model Contextual Teaching and Learning (CTL) membutuhkan peran guru untuk meningkatkan hasil dari kegiatan permbelajaran. Guru kelas V di SD Advent Pekanbaru sudah menunjukkan perannya dalam mengajar siswa. Hal ini terlihat guru sudah melakukan peran sebagai perencana (membuat RPP sebelum pembelajaran berlangsung), guru sebagai pelaksana (guru 
menggunakan model contextual teaching and learning dalam menyampaikan materi ajar) dan guru sebagai penilai (evaluator).

\section{DAFTAR PUSTAKA}

Alfansyur, A., \& Mariyani. (2020). Seni Mengelola Data: Penerapan Triangulasi Teknik, Sumber Dan Waktu Pada Penelitian Pendidikan Sosial. HISTORIS: Jurnal Kajian, Penelitian \& Pengembangan Pendidikan Sejarah, 5(2), 146-150.

Buchari, A. (2018). Peran Guru Dalam Pengelolaan Pembelajaran. Jurnal Ilmiah Iqra', 12(2), 106. https://doi.org/10.30984/jii.v12i2.897

Dafit, F., \& Ramadan, Z. H. (2020). Pelaksanaan Program Gerakan Literasi Sekolah (GLS) di Sekolah Dasar. Jurnal Basicedu, 4(4), 1429-1437. https://doi.org/10.31004/basicedu.v4i4.585

Febrina, F., Hajidin, \& Mahmud. (2016). KOMPETENSI GURU DALAM PERENCANAAN PEMBELAJARAN DI SDN 2 BANDA ACEH Febi Febrina, Hajidin, Mahmud. Ilmiah Mahasiswa Prodi PGSD, 1, 40-50.

Hadi, S. (2016). Pemeriksaan Keabsahan Data Penelitian Kualitatif Pada Skripsi [Examination of the Validity of Qualitative Research Data on Thesis]. Ilmu Pendidikan, 22(1), 21-22.

Hafifah, F., Nurimani, N., \& ... (2019). Perbedaan Model Pembelajaran Contextual Teaching and Learning dan Jigsaw terhadap Hasil Belajar Matematika. Prosiding ..., 1-5. http://jurnal.stkipkusumanegara.ac.id/index.php/semnara2019/article/view/205

Istiningsih, G., L.A, E. M., \& Prihalina, E. (2018). Pengembangan Model Pembelajaran "Promister" untuk Meningkatkan Hasil Belajar Wayang Pandhawa Pada Siswa Sekolah Dasar. Jurnal Holistika, $I I(2)$, 94-103. https://jurnal.umj.ac.id/index.php/holistika/article/download/2637/2788

Jamalia, J. (2018). Model Ctl Untuk Meningkatkan Hasil Belajar Matematika Kelas V Sdn 104/Ix Kedemangan. Refleksi Edukatika: Jurnal Ilmiah Kependidikan, 9(1). https://doi.org/10.24176/re.v9i1.2812

Kirom, A. (2017). Peran Guru Dan Peserta Didik Dalam Proses Pembelajaran. Al Murabbi, 3(1), 6980. http://jurnal.yudharta.ac.id/v2/index.php/pai/article/view/893

Muklis, M. (2012). Pembelajaran Tematik PEMBELAJARAN TEMATIK Mohamad Muklis STAIN Samarinda. Fenomena, IV(1), 63-76. 
Setiawati, S. M. (2018). 'HELPER” Jurnal Bimbingan dan Konseling FKIP UNIPA. Jurnal Bimbingan Dan Konseling FKIP UNIPA, 35(1), 31-46.

Sugiyono. (2017). Metode Penelitian Kuantitatif Kualitatif dan R\&D. Alfabeta.

Sungkono, S. (2006). Pembelajaran Tematik Dan Implementasinya Di Sekolah Dasar. Majalah Ilmiah Pembelajaran, 2(1), 51-58.

UDIAT, E. (2019). Kreativitas Guru Dalam Pemanfaatan Media Pada Mata Pelajaran Matematika $\mathrm{Di}$ Kelas Iv $\mathrm{Mi}$ Ma'Arif $\mathrm{Nu} 02$ Tangkisan Kecamatan Mrebet .... http://repository.iainpurwokerto.ac.id/6007/ 
PERAN GURU DALAM MENGGUNAKAN MODEL CONTEXTUAL TEACHING AND LEARNING (CTL) ...

Dahlia Mei Frida Silitonga, Elpri Darta Putra 